\title{
ANALISIS KESALAHAN KOHESI DAN KOHERENSI DALAM \\ KARANGAN DESKRIPSI SISWA KELAS X SMK SWASTA \\ DHARMA PATRA PANGKALAN SUSU \\ TAHUN PEMBELAJARAN \\ 2016/2017
}

Oleh

Siti Sumarni (Sitisumarni27 @ gmail.com)
Drs. Sanggup Barus, M.Pd.

\begin{abstract}
ABSTRAK
Kohesi adalah salah satu standar yang menandai bahwa sebuah teks atau wacana itu dianggap komunikatif, tanpa kohesi teks atau wacana tidak dianggap komuikatif dan setiap unsur-unsur di dalammnya saling berhubungan. Sedangkan koherensi dalam kalimat atau paragraf adalah hubungan timbal balik yang logis, kompak dan baik antarkalimat atau unsur - unsur yang membentuk kalimat atau paragraf bahkan sebuah karangan. Penelitian ini merupakan penelitian deskriptif kualitatif. Penelitian ini menggunakan karangan siswa kelas X SMK Swasta Dharma Patra Pangkalan Susu sebagai subjek penelitian, yang dipilih sebanyak 30 karangan. Teknik penentuan subjek didasarkan pada pengambilan sampel yang dilakukan secara random sampling, yaitu dari 4 kelas paralel diambil 1 kelas, yaitu kelas X TKJ-1. Adapun objek penelitiannya adalah kesalahan kohesi dan koherensi. Metode analisisnya menggunakan metode analisis deskriptif kualitatif. Instrument yang digunakan pada penelitian ini adalah human instrument. Hasil penelitian ini menunjukkan bahwa jumlah total kesalahan yang ditemukan sebanyak 26 kesalahan yang terdiri dari 17 kesalahan kohesi dan 9 kesalahan koherensi.
\end{abstract}

Kata Kunci: Analisis, Kohesi, Koherensi

\section{PENDAHULUAN}

Menulis sebagai salah satu kemampuan bahasa bukanlah kemampuan yang diwariskan secara turun-temurun. Menyusun suatu gagasan menjadi rangkaian bahasa tulis yang teratur, sistematis, dan logis bukanlah merupakan pekerjaan yang mudah, melainkan pekerjaan yang memerlukan latihan terus-menerus dan 
berkesinambungan. Menulis merupakan salah satu kemampuan yang perlu dimiliki oleh siswa sejak sekolah dasar sampai sekolah lanjutan. Dengan memiliki kemampuan menulis cakrawala berpikir kreatif dan kritis siswa dapat berkembang. Selain itu, keterampilan ini akan menunjang kelanjutan studi mereka ke lembaga pendidikan yang lebih tinggi maupun bekal untuk bekerja.

Menurut Tarigan (2005: 21), menulis adalah menurunkan atau melukiskan lambang-lambang grafik yang menghasilkan suatu bahasa yang dipahami oleh seseorang sehingga orang lain dapat membaca lambang-lambang grafik tersebut dan dapat memahami bahasa dan grafik itu.

Sebagai pengungkapan ide-ide tertentu, sebuah karangan harus memiliki kesatuan dan keutuhan tulisan yang dapat mencerminkan ide atau permasalahan yang ingin diungkapkan oleh penulis. Sehingga informasi atau hal-hal yang ingin diungkapkan oleh penulis dapat dipahami oleh pembaca dari berbagai latar belakang sosial.

Sebuah karangan dikatakan terlengkap karena mencakup tataran di bawahnya yakni fonologi, morfologi, sintaksis, semantik, dan ditunjang oleh unsur lainnya, yaitu situasi pemakaian dalam masyarakat. Karangan atau wacana dibentuk oleh paragraf-paragraf sedangkan paragraf dibentuk oleh kalimatkalimat.Yang membentuk paragraf itu haruslah merangkai kalimat satu dengan kalimat berikutnya dan harus berkaitan sehingga membentuk satu kesatuan (kohesi) yang utuh atau membentuk suatu gagasan yang padu (koherensi).

Hanafiah (2014: 135) mengemukakan, "Kohesi adalah suatu alat pengikat yang membuat sesuatu menjadi teks atau wacana." Menurut Renkema (dalam Wardah, 2014: 138), koherensi adalah jalinan antar bagian dalam wacana; kepaduan semantis yang dapat dicapai oleh faktor-faktor di luar wacana.

Keutuhan sebuah karangan itu sendiri dibangun oleh komponenkomponen yang terjalin di dalam suatu organisasi kewacanaan. Keutuhan dalam tulisan dapat mencakup kohesi dan koherensi yang ada di dalam tulisan tersebut. Keduanya merupakan bagian yang mutlak yang harus ada di dalam suatu wacana yang baik. Jika keduanya tidak terdapat di dalam sebuah karangan maka paragraf tersebut dikatakan tidak utuh dan koheren. 
Sejalan dengan pendapat di atas, Anie Wulandari (2015: 178) mengemukakan bahwa kohesi dan koherensi merupakan bagian yang penting untuk mendapatkan penulisan paragraf yang utuh. Anie juga mengemukakan hasil penelitiannya tentang kesalahan kohesi dan koherensi, yaitu data paragraf koheren yang terdapat dalam 306 paragraf data penelitian adalah sebanyak 272 data dan paragraf tidak koheren sebanyak 34 data.

Diah (2012: 64) hasil penelitian kesalahan kohesi dan koherensi pada karangan siswa kelas $\mathrm{X}$ diperoleh sebanyak 75 kesalahan yang terdiri dari alat kohesi maupun alat koherensi. Kesalahan tersebut karena siswa belum memahami bagaiman bentuk paragraf yang utuh dan koheren.

Nisa (2011: 27) berdasarkan pada penelitian yang telah dilakukan, terdapat empat jenis kesalahan pada sarana kohesi gramatikal, dan tiga jenis sarana kohesi leksikal. Keempat jenis sarana kohesi gramatikal meliputi: (1) kohesi penunjukan, (2) kohesi penggantian, (3) kohesi pelesapan, dan (4) kohesi perangkaian. Sedangkan ketiga jenis kesalahan pada sarana kohesi leksikal meliputi: (1) repetisi, (2) sinonimi, dan (3) antonimi.

Kemudian berdasarkan observasi yang dilakukan oleh peneliti kepada salah satu guru Bahasa Indonesia di SMK Swasta Dharma Patra Pangkalan Susu, beliau menyatakan bahwa nilai rata-rata siswa dalam menulis karangan deskripsi hanya mencapai 69, sementara KKMnya adalah 75 maka penulis tertarik untuk melakukan sebuah penelitian untuk menganalisis kesalahan kohesi dan koherensi dalam karangan siswa kelas X SMK.

Terlihat jelas kenyataannya bahwa masih banyak siswa yang belum menguasai bagaimana menulis sebuah karangan yang baik dan benar. Jika dilihat dari bentuk dan maknanya masih terdapat ketidaksesuaian antara bentuk dan makna. Siswa hanya sekedar menuliskan ide yang di dapatnya namun tidak memperhatikan kohesi dan koherensi yang terdapat di dalam karangan tersebut. Hal tersebut dikarenakan kemampuan menulis siswa masih rendah.

Kemampuan menulis masih rendah dikarenakan selama ini siswa menilai pelajaran Bahasa Indonesia di sekolah kurang menunjukkan hasil yang memuaskan dan masih jauh dari harapan. Siswa kurang memiliki pengalaman 
berbahasa yang baik. Di antaranya kemampuan menulis yang kurang memadai, kebiasaan membaca yang tidak sesuai, kesalahan penalaran (logika berbahasa), menyalahi kaidah bahasa Indonesia, adanya pengaruh bahasa pertama, penyusun kalimat, pembentuk paragraf, serta belum mampu mengapresiasi dan berekspresi sastra sesuai dengan yang diharapkan.

\section{METODE PENELITIAN}

Metode merupakan rangkaian teknik atau cara untuk mencapai tujuan penelitian. Sedangkan metode penelitian adalah cara untuk mencapai tujuan penelitian. Dapat disimpulkan metode penelitian adalah cara yang digunakan peneliti untuk mencari data kemudian diaplikasikan terhadap objek yang diteliti.

Metode yang digunakan dalam penelitian ini adalah metode deskriptif kualitatif. Menurut Moleong (dalam Diah Dwi, 2012: 55), penelitian kualitatif adalah penelitian yang bermaksud untuk memahami fenomena tantang apa yang dialami oleh subjek penelitian, secara holistik dengan cara deskripsi dalam bentuk kata-kata dan bahasa, pada suatu konteks khusus yang alamiah dan dengan memanfaatkan berbagai metode alamiah.

Metode deskripsi kualitatif mendeskripsikan secara intensif dan terperinci tentang kesalahan paragraf dalam karangan siswa kelas X SMK Swasta Dharma Patra Pangkalan Susu. Jadi, penelitian ini menggunakan pendekatan deskriptif analisis karena hasil dari penelitian ini berupa data deskriptif dalam bentuk kata tertulis.

\section{HASIL PENELITIAN DAN PEMBAHASAN}

Setelah dilakukan penelitian, diperoleh kesalahan penggunaan kohesi dan kesalahan penggunaan koherensi dalam paragraf pada karangan siswa SMK Swasta Dharma Patra Pangkalan Susu. Hasil penelitian kesalahan kohesi dan koherensi pada karangan siswa kelas X diperoleh sebanyak 29 kesalahan, yang terdiri dari 20 kesalahan kohesi dan 9 kesalahan koherensi. Berikut ini kesalahan kohesi dan koherensi pada karangan siswa kelas X SMK Swasta Dharma Patra Pangkalan Susu. 


\section{Kesalahan Kohesi}

Kesalahan kohesi ini terdiri dari 17 kesalahan dari hasil analisis 30 karangan siswa. Pada kesalahan kohesi banyak siswa yang kurang tepat dalam menggunakan konjungsi dengan tepat dan baik. Selain itu siswa tidak memperhatikan keserasian hubungan antar unsur yang satu dengan unsur yang lain dalam karangan sehingga karangan tersebut menjadi tidak padu atau koheren. Berikut ini hanya dijelaskan beberapa kesalahan kohesi pada karangan siswa kelas X SMK Swasta Dharma Patra Pangkalan Susu.

\section{Data 1:}

"Aku sengaja minta dengan orang tuaku untuk mendekorasi kamarku secantik mungkin agar aku merasa nyaman saat di dalam kamar" (001/Pm.K/Pr.2).

Pada kalimat di atas terdapat kesalahan kata sambung yang artinya tidak sesuai dengan makna yang sebenarnya. Kesalahan di atas termasuk ke dalam kesalahan penggunaan konjungsi yang tidak tepat, yaitu penggunaan kata dengan. Penggunaan kata sambung dengan pada kalimat di atas tidak sesuai karena kata dengan digunakan untuk menyatakan hubungan cara, maka sebaiknya digunakan kata sambung kepada. Kalimat yang benar menjadi: “Aku sengaja minta kepada orang tuaku untuk mendekorasi kamarku secantik mungkin agar aku merasa nyaman saat di dalam kamar" (001/Pm.K/Pr.2).

\section{Data 2:}

"Kami semua senang mempunyai kepala sekolah yang bisa mendekatkan diri kepada siswa-siswanya. Kami sangat menghormatinya seperti orang tua kami sendiri dan karena itulah kami selalu mendapatkan tawa canda jika bersamanya" (008/Pm.K/Pr.3).

Pada data 2 juga terdapat dua konjungsi yang berdampingan, yaitu dan karena. Kedua konjungsi tersebut memiliki makna dan fungsi yang berbeda sehingga tidak dapat digunakan secara bersamaan. Konjungsi dan digunakan untuk menggabungkan dua hal atau peristiwa sedangkan konjungsi karena termasuk ke dalam konjungsi sebab (kausal) yang berfungsi untuk menjelaskan bahwa suatu peristiwa terjadi karena suatu sebab akibat tertentu. Jika dilihat dari 
kalimatnya maka pada data 3 ini sebaiknya menghilangkan konjungsi dan dan hanya menggunakan konjungsi karena. Kalimat yang benar menjadi: "Kami semua senang mempunyai kepala sekolah yang bisa mendekatkan diri kepada siswa-siswanya. Kami sangat menghormatinya seperti orang tua kami sendiri karena itulah kami selalu mendapatkan tawa canda jika bersamanya" (008/Pm.K/Pr.3).

\section{Data 3:}

"Aku berharap dia dapat merubah kebiasaan jeleknya di dalam kelas dan supaya dia dapat merubah sikapnya tidak melawan guru lagi” (004/Pm.K/Pr.6).

Pada data 3 juga terdapat dua konjungsi yang berdampingan, yaitu dan supaya. Kedua konjungsi tersebut memiliki makna dan fungsi yang berbeda sehingga tidak dapat digunakan secara bersamaan. Konjungsi dan digunakan untuk menggabungkan dua hal atau peristiwa, sedangkan konjungsi supaya termasuk ke dalam konjungsi final (tujuan) yang berfungsi untuk menjelaskan maksud atau tujuan suatu peristiwa atau tindakan. Jika dilihat dari kalimatnya maka konjungsi dan dihilangkan agar kalimat menjadi tepat. Perbaikan kalimatnya menjadi: "Aku berharap dia dapat merubah kebiasaan jeleknya di dalam kelas supaya dia dapat merubah sikapnya tidak melawan guru lagi” (004/Pm.K/Pr.6).

\section{Data 4:}

"Suatu hari minggu banyak orang yang berbondong-bondong mau bergotong royong di pantai. Mereka membawa peralatan masingmasing dari rumah" (007/Pm.K/Pr.4).

Pada data 4 kesalahan kohesi terletak pada penggunaan konjungsi terletak pada penulisan suatu hari minggu yang menyebabkan pemborosan kata pada kalimat tersebut. Kalimat tersebut menjadi tidak padu karena menggunakan frasa suatu dan hari minggu. Sebaiknya menggunakan salah satu saja, apakah suatu hari atau hari minggu karena kedua kata tersebut sama-sama merujuk pada konjungsi waktu. Kalimat yang benar menjadi: "Hari minggu banyak orang yang berbondong-bondong mau bergotong royong di pantai. Mereka membawa peralatan masing-masing dari rumah" (007/Pm.K/Pr.4). 


\section{Data 5:}

"Sedari aku masih dikandungan dia menjagaku dan merawatku di dalam rahimnya dan Sembilan bulan aku dikandungnya" (009/Pm.K/Pr.2).

Pada data 5 kesalahan terletak pada penggunaan konjungsi dan yang tidak sesuai dengan kalimat. Konjungsi dan digunakan untuk menggabungkan dua kata, namun pada kalimat ini penggunaannya tidak tepat. Kalimat yang benar menjadi: "Sedari aku masih dikandungan dia menjagaku dan merawatku di dalam rahimnya selama sembilan bulan aku dikandungnya" (009/Pm.K/Pr.2).

\section{Data 6:}

"Dan setiap hari kami belajar dengan guru yang sangat baik dan terkadang kami juga bercanda bersama saat jam istirahat" (008/Pm.K/Pr.2).

Data di atas kesalahan konjungsinya terletak pada penulisan kata dan yang ditulis di awal kalimat. Konjungsi dan tidak dibolehkan ditulis di awal kalimat karena konjungsi dan digunakan untuk menghubungkan dua atau lebih klausa yang sederajat, maka sebaiknya hilangkan konjungsi dan di awal kalimat. Perbaikan kalimatnya adalah: "Setiap hari kami belajar dengan guru yang sangat baik dan terkadang kami juga bercanda bersama saat jam istirahat" (008/Pm.K/Pr.2).

\section{Kesalahan Koherensi}

Dari hasil analisis pada karangan siswa terdapat 9 kesalahan koherensi. Hal tersebut dikarenakan siswa tidak memperhatikan kekompakan hubungan antarkalimat dalam karangan. Selain itu siswa tidak mengurutkan dengan benar satu persatu kalimat untuk menjadi karangan yang baik sehingga karangan tersebut tidak mencapai maksud dengan tepat atau tidak logis. Berikut ini beberapa hasil analisis kesalahan koherensi yang terdapat pada penulisan karangan dalam karangan siswa kelas X SMK Swasta Dharma Patra Pangkalan Susu. 


\section{Data 7:}

"Semuanya dikerjakan kakak dan siang harinya kakak menidurkan anaknya dan memandikannya sampai bersih dan akupun tidur" (010/Pm.Kb/Pr.3).

Pada data di atas terjadi kesalahan koherensi karena pada paragraf tersebut tidak ada hubungan makna yang dapat dipahami. Pada data tersebut seharusnya menjadi : "Semuanya dikerjakan kakak dan siang harinya kakak menidurkan anaknya dan memandikannya sampai bersih sementara itu akupun tidur" (010/Pm.Kb/Pr.3).

\section{Data 8:}

"Saat aku beranjak dewasa aku melawan padanya, aku membantah apa yang ibu suruh padaku, tanpa sadar aku suka meminta padanya" (009/Pm.Kb/Pr.6).

Data di atas terdapat kesalahan koherensi yaitu kalimatnya masih kurang lengkap agar lengkap kalimat tersebut ditambahkan konjungsi sementara itu. Dengan begitu kalimat menjadi lengkap. Kalimat yang benar adalah: "Saat aku beranjak dewasa aku melawan padanya, aku membantah apa yang ibu suruh padaku sementara itu, tanpa sadar aku suka meminta padanya" (009/Pm.Kb/Pr.6).

\section{Data 9:}

"Tidak ada ibu yang tidak mencintai anaknya. Jikapun ada, itu pasti bukan dari hatinya yang sebenarnya" (022/Pm.Kp/Pr.1).

Dari data tersebut terjadi kesalahan koherensi karena pemakian morfem nya yang tidak sesuai. Morfem nya pada kata hati merujuk pada kata sifat sedangkan kata sebenarnya menjelaskan maksud yang dituju benar. Maka sebaiknya morfem nya pada kata hati dihilangkan agar kalimat menjadi tepat. Kalimat yang benar, yaitu: “Tidak ada ibu yang tidak mencintai anaknya. Jikapun ada, itu pasti bukan dari hati yang sebenarnya" (022/Pm.Kp/Pr.1).

\section{Data 10:}

"Setiap harinya semua keluarga saya melakukan aktifitas, kakak saya bekerja, ayah saya bekerja, adik saya masih bersekolah, mamak saya memasak dan membersihkan rumah" (003/Pm.Pb/Pr.4). 
Pada data di atas menunjukkan sebuah paragraf perbandingan namun pada kedua kalimat tersebut belum ada pembeda antara yang dibandingkan dan pembandingnya. Paragraf tersebut akan lebih mudah dipahami jika antara pembanding dan yang dibandingkan diberi kata penghubung sedangkan atau sebaliknya, sehingga kalimat tersebut menjadi: "Setiap harinya semua keluarga saya melakukan aktifitas, kakak dan ayah saya bekerja, adik saya masih bersekolah, sedangkan mamak saya memasak dan membersihkan rumah" (003/Pm.Pb/Pr.4).

\section{Pembahasan}

Setelah dijelaskan hasil analisis kesalahan kohesi dan koherensi maka dapat diketahui pembahasan yang lebih rinci tentang kesalahan kohesi dan koherensi tersebut. Berikut adalah penyajian beberapa pembahasan dari kesalahan kohesi dan kesalahan koherensi pada karangan siswa SMK Swasta Dharma Patra Pangkalan Susu.

\section{Kesalahan Kohesi}

Kesalahan kohesi pada karangan siswa ini disebabkan siswa tidak memahami dengan baik cara pengulangan kata baik secara menyeluruh maupun sebagian dan sesuai dengan kaidah tata bahasa Indonesia. Menurut Kurniasari (2016:12) dalam penelitiannya, menjelaskan bahwa siswa kurang memahami materi dan kurang latihan. Selain itu, materi pembelajaran dalam kurikulum yang sekarang tidak diajarkan secara mendalam. Jadi, guru mengajarkan tersendiri dengan menyelipkan materi tersebut pada saat mengajar. Kesalahan tidak hanya pada kalimat, tetapi juga pada ejaan dan tanda baca. Kesalahan itu terjadi karena siswa kurang memahami materi yang diajarkan.

\section{Kesalahan Koherensi}

Kesalahan koherensi adalah karena kurangnya pemahaman siswa dalam memahami materi tentang koherensi. Siswa sulit dalam hal mengungkapkan makna yang sebenarnya sehingga tidak membentuk unsur-unsur kalimat yang sesuai. Kebanyakan siswa tidak dapat menyatukan beberapa hal yang berlawanan dalam satu paragraf menjadi kalimat perbandingan sehingga menjadi koheren. 
Faktor lain yang menyebabkan kesalahan koherensi yaitu karena kesalahan penalaran yang terjadi apabila pada kata-kata dalam kalimat tersebut tidak sesuai dengan keadaan yang sesungguhnya atau tidak logis. Siswa juga tidak dapat menguraikan hal-hal yang kecil, satu demi satu menjadi yang sebenarnya.

\section{PENUTUP}

Berdasarkan hasil penelitian dan pembahasan yang telah diuraikan dapat diperoleh simpulan, yaitu kesalahan kohesi dalam karangan siswa kelas X SMK Swasta Dharma Patra Pangkalan Susu ditemukan 17 kesalahan, yaitu kesalahan dalam penggunaan konjungsi yang kurang tepat seperti: dengan, dan, karena, setelah itu, yang, hanya. Kemudian kesalahan pada penggunaan kata ganti diri, seperti: aku, kita. Pada kesalahan kohesi yang lebih dominan terjadi kesalahan karena kesalahan penggunaan konjungsi yang kurang tepat.

Sedangkan pada kesalahan koherensi dalam karangan siswa kelas X SMK Swasta Dharma Patra Pangkalan Susu ditemukan 9 kesalahan, yaitu kesalahan dalam membandingkan, seperti: sedangkan atau sebaliknya. Selain itu kesalahan dalam memberi rincian, seperti: terdiri dari, seperti. Pada kesalahan koherensi kesalahan yang sering terjadi karena siswa tidak memperhatikan dengan benar susunan antarkalimat dengan benar untuk mewujudkan sebuah karangan yang baik dan logis.

\section{DAFTAR PUSTAKA}

Azis, Anie Wulandari. 2015. Koherensi Paragraf dalam Skripsi Mahasiswa Prodi Pendidikan Bahasa dan Sastra Indonesia. Vol:1, No:2. (diakses tanggal 19 Desember 2016)

Hanafiah, Wardah. 2014. Analisis Kohesi Dan Koherensi Pada Wacana Buletin Jumat. Vol.11 No. 2 Oktober 2014:135-152. Epigram. (diakses pada tanggal 30 Maret 2017 pukul 10.00)

Kurniasari, Agnes Heppy, dkk. 2016. Peranti Kohesi Gramatikal Dan Leksikal Pada Tulisan Deskripsi Siswa Kelas VIII Smp Dan Relevansinya Sebagai Materi Ajar Bahasa Indonesia. Jurnal Penelitian Bahasa, Sastra Indonesia dan Pengajarannya Volume 4 Nomor 1, April 2016, ISSN I2302-6405 . BASASTRA. (diakses tanggal 17 Juli 2017) 
Kurniyati, Diah Dwi. 2012. Analisis Kesalahan Kohesi dan Koherensi Paragraf pada Karangan Siswa Kelas X SMA Negeri 3 Temanggung. Yogyakarta: Universitas Negeri Yogyakarta

Tarigan, HG. 2005. Menulis Sebagai suatu Kemahiran Berbahasa. Bandung: Angkasa 